\title{
An Investigation About Some Difficulties Encountered by Libyan University First Year Students in Writing English Paragraphs via Computers, A Comparative Case Study between the Traditional Way and the Modern Way of Writing English Paragraphs
}

\author{
Marwa Issa Hneesh
}

\author{
Dr. Fawzia Abugela Salem Albawe
}

\author{
Abugela Abdulah Asheny
}

\begin{abstract}
English writing is one of the most important means of communication and contacting today, it is necessary to maintain this skill correct and professional. The students have to develop their communicative skills, especially writing skills. Effectively, for those who wish to be professional persons in their lives, and also for their higher studies. Gardner and Johnson (1997) summed up the stages of the writing process as follows: prewriting rough draft, reread share with a peer reviser, revise, editing, final draft publishing. Learners are enabled to take charge of their writing process and interact with each other and the instructor works as a facilitator, organizer and even a creator of a learning environment to generate learners motivation, especially to enhance their intrinsic motivation and to make the autonomous writers. Learner's attitude to the learned language impacts the learner outside the classroom (Schumann, 1978; Dornyei \& Skehan, 2003; Csizer \& Dornyei, 2005a, 2005b). A favorable attitude would motivate learners to reach their learning goals as found by Burden (2004) who studied attitude change of Japanese university students in an English conversation class. Gardner et al. (2004) also argued that affective factors influence language acquisition and achievement. They studied the effects of language instruction on "language attitudes, motivation, and anxiety that take place over the academic year" (p. 7) and used the Attitude Motivation Test Battery (AMTB) to measure variables which are important in the socio-educational model such as motivation intensity, desire to learn French, attitudes to learning French and to French Canadians, and interest in foreign languages. They also evaluated the French teacher and the course, the anxiety in the French class and in using French, and whether learning French is instrumental to the participants. Findings show that students' attitudes are influenced by the teacher and the classroom environment; experiences in different classes varied and had different effects on students' interest in foreign languages. This study aims to make some Libyan University students at English departments better writers by looking after the problems that face them in their writings. By using the electronic way, students should practice something called Word-Processing Software installed in computers. Before using any type of word-processing software, there certain terminology that one needs to become familiar with ,in order to create documents. In Microsoft word, some terminologies are used to particulate certain features of the software program, its functional waving ion methods, and common word-processing terms. Arrow key, close, sow, border, click, double chick, and many more regarding writing skills editing is all important. By editing, deleting, moving, or adding characters, changing font styles, inserting bulleted items, and altering the color or text, can modify documents Ibid. Bangert-Drowns (1993) stated that while editing the text, the users have the opportunity to proofread, to add further explanation, to develop ideas, and to restructure the text, so the users can understand the weaknesses and the provision to overcome the difficulties and to apply knowledge
\end{abstract}


of language. Thus, it can be surmised that a computer gives enough flexibility to utilizing the resources in learning and developing writing skills. This study includes five chapters. In chapter one the researchers wrote about the main idea that they were looking for ,the struggles, and their solutions for those problems, in addition to the question that should be the answered by the subjects during the searching process in this Introductory Part. Chapter two is about the literature and some authors who worked previously about the same topic, and this part is called Literature Review Part. Chapter three is about the analysis of the data which being collected for the study and it is called Methodology Part. Chapter four is about the discussion of the results of chapter three, and it is called Discussion and Results part. Chapter five is about finding of the solutions for the problems that the researchers suggested in chapter one, and for the problems that found while studying the results in chapter four, so the researchers concluded and gave some recommendations that could be useful to the students and teachers also, and it is called Conclusion and Recommendations part.

Key Words: traditional way, via computer, writing skills, university students, teachers, writing techniques

\section{Background to the study:}

\section{INTRODUCTION}

Writing helps to describe our thoughts, emotions, and situations. It helps the writer to show his/her point of views. This research will investigate the best way to teach English paragraph writing either it is traditionally, or electronically (i.e. via computer), by teaching and focusing on the first year students, English department among Libyan universities in how to write a good paragraph.

\section{Aims of the study :}

This study aims to investigate how English writing is being taught, how the traditional way is effecting their skills in writing a paragraph, and how is the electronic way effecting their skills too. This study is answering the following questions:

1- What are the advantages of teaching paragraph writing via computer?

2- How the students' skills being affected by the electronic way of writing a paragraph via computer?

3- Do computers increase the learners' motivation in learning English paragraphs?

\section{Hypotheses}

It is hypothesized by the researchers that most Libyan university first year students have no enough knowledge to improve their English writing skills via computers, especially in writing good paragraph.

\section{The significance of the study:}

The researchers chose this topic due to:

1. improve and support paragraph writing at English Department generally, and especially first year students.

2. help the student to apply his/her skills easily, and to be a creative writer.

3. improve that first year student can write better if he/she studies paragraph writing via computers way.

The Paragraph

\section{LITERATURE REVIEW}

Byrne (1971) said that a paragraph is usually a group of sentences closely concerned with one idea. A paragraph can be as short as one sentence or as long as ten sentences. 


\section{The Three Parts of Paragraph}

A paragraph has three structural parts which are: A topic sentence, supporting sentences, and a concluding sentence.

\section{1- The Topic Sentence.}

Oshima and Alize (1978) mentioned in details that, the topic sentence contains the main idea of the paragraph, but also limits the topic to one or two areas that can be discussed completely in the space of a single paragraph.

\section{A - Position of Topic Sentence:}

The topic sentence might be found in any position in a paragraph, it should be, whenever possible places at the beginning because the reader will find it easier to decide what information to read about.

\section{B - Elements of a Topic Sentence}

A topic sentence has two main parts: the topic and the controlling idea. The following sentence is an example:

Topic controlling idea

Convenience food is easy to prepare

\section{2- The Supporting Sentences :}

The supporting sentences usually come after the topic sentence supporting up the body of the paragraph. They give details to develop the main idea of the paragraph.

\section{3 - The Concluding Sentence:}

A concluding sentence is helpful to the reader and it comes at the end of the paragraph because it reminds him /her to the writer's important points.

1- It signals the end of the paragraph.

2- It summarizes the main point of the paragraph.

3- It gives the final comment on the writer's topic and leaves the reader with the most important ideas to think about.

\section{Characteristics of a Good Paragraph :}

Unity:

A paragraph has a unity when each sentence is clearly related to the controlling idea and when no important information about the controlling idea is missing.

\section{Coherence:}

A paragraph has the quality of coherence when all parts stand together in systematic arrangement. The information and ideas should be arranged in a logical order and there should be clear transitions from sentence to another.

\section{Punctuation Marks.}

Punctuation marks are very important, they have their own meanings, and these are the meaning supplements of words. The purpose of punctuation marks is practical, not ornamental. The reason for punctuation is to make the meaning clear.

Non End Punctuation Mark:

A- The comma (,).

B- The semi-colon (:). 


\section{End Punctuation Mark :}

A- The full stop(.).

B -The question mark(?).

C- The exclamation mark(!).

\section{Punctuation Mark Used within the Word :}

A-The apostrophe(').

\section{Electronic Word Processor Software and English Paragraph Writing Skill.}

The word processor is a computer program equipped with facilities for editing and checking grammatical, spelling, and style errors and correcting them.

Word processor is a common kind of software. As its name implies, word processor process paragraphs, pages, and entire papers. The most widely used word processor is Microsoft Word that we can find in Windows which is designed to help people in the composition process.

Neey hapuzee (2011) reported that, Word processor is common kind of software and she explained that in details by saying that: As its name implies, word processor process paragraphs, pages, and entire papers. The most widely used word processor is Microsoft Word that one can find in Windows which is designed to help people in the composition process.

Word processor, in this case MS Word, offers some handy tools under its Tools menu which can be applied in improving writing skill. For examples:

Spell checking: it tells the users that the word is incorrectly written, so it can build their vocabulary power.

Grammar checking: it checks for what seem to be simple grammar errors and gives the users list of possible suggestion about the grammar of text in the document. It is one of the most important features as it can be taken by the users as a learning media.

Thesaurus: this feature can help the users finding out the right words to choose because it suggests other word with a similar meaning to the word the users selected.

Dictionary: it is used in language learning as a resource and the users can use this resource for developing language skills especially writing skills.

\section{Effects of the Electronic Ways of Writing on Motivation of Learning English Writing Skills}

Rima Bahous, Nahla Nola Bacha, and Mona Nabhani, (2011) wrote that motivating EFL students to develop in the target language is quite complex. In many cases, these students face difficulties in learning English and are often demotivated to learn. Research in classroom motivation has found that certain strategies can help these students adopt more positive attitudes and become more motivated in the learning process. This exploratory study investigates the perceptions through interviewing students and surveying teachers' views in an EFL Program of the problems that hinder these students' learning in the English classes related to motivation. Findings show that learners are not motivated to learn English because of an over-focus on writing skills with very little new learning experiences, uninteresting materials, and unclear links between language courses and their majors or future careers. Results also indicate that teachers complain of unmotivated students and pre-structured 
syllabi leaving little room for communicative methods. Implications are made for the classroom.

Moreover, Kulik (2003) claimed that in three out of the four studies that have been conducted, word processing produced significant positive effects on student writing skills. He also asserted with regular use of word processors, young writers might even get into the habit of revising and reorganizing their compositions, and this habit might affect the quality of their writing even when they were writing with paper and pencil alone.

\section{METHODOLOGY}

The researchers collected the data for the study in this chapter. The data contained the information and techniques used in writing a paragraph .The sample of the study (university first year students) , answered two questionnaires given by the researchers, and their personal points of view were evaluated regarding their abilities to use these techniques in writing a paragraph.The researchers gave a brief introduction to some common errors analysis, after presenting and discussing the data.

\section{The Subjects of the Present study:}

The subjects of this research were first year students, English Department, college of Arts, Zwara. The students were randomly picked up ,they were six students ,their ages are between eighteen, nineteen, and twenty years . They are four females, and two males, they studied English for eight years in primary, preparatory, and secondary schools. Arabic is their mother tongue, The main reasons of choosing first year student are:

1- First year students are supposed to learn English Writing, how to write a paragraph, and what are the techniques on general topics in English.

2- In their eight- year studying English, their book was ENGLISH FOR LIBYA, they didn't study techniques in writing a paragraph, so they learn them in first year, but with traditional way; that makes writing is worthless, and not interesting subject.

\section{Data for the Study:}

To achieve good results, it was very important to know the students capacities of writing a paragraph, in that the researchers made simple questionnaire which were helpful to figure out what was the level they were in. First year students, Zwara Collage which lie in Zwara City within area i.e. from the west of Sabratah City to east of Ras AL-jdeer, it is on Mediterranean sea .The first questionnaire contained four different parts. The first part of the questionnaire was about how they evaluate their typing, taking courses, and how they deal with via computer competence. The second part was about how they are affected by using technology. The third part and the last was asked them to write a paragraph. But the practical activity was given to them after giving a lecture in lab, and it was only one question to write a paragraph, the topic was free to choose.

\section{Analysis of a Questionnaire Given by the Researchers and Answered by the Students via Pens and Papers (Traditionally):}

This part of the research contained the analysis of the whole questionnaire, how the researchers evaluated the students' abilities, and how they feel toward using computers in their studying. The analysis, the sample were as the follows:

\section{1-The Percentages of the Answers Given by the Students Regarding Learning English} Paragraph Writing 


\section{The results of the first question in the questionnaire were:}

In this question, only 1 of the students rated his/her ability poor, so percentage was (16.6\%). Also only 1 of the students rated his/her ability fair, so the percentage was(16.6\%).But 4 of them rated it good, so the percentage was (66.6\%).And no one rated his/her ability very good.

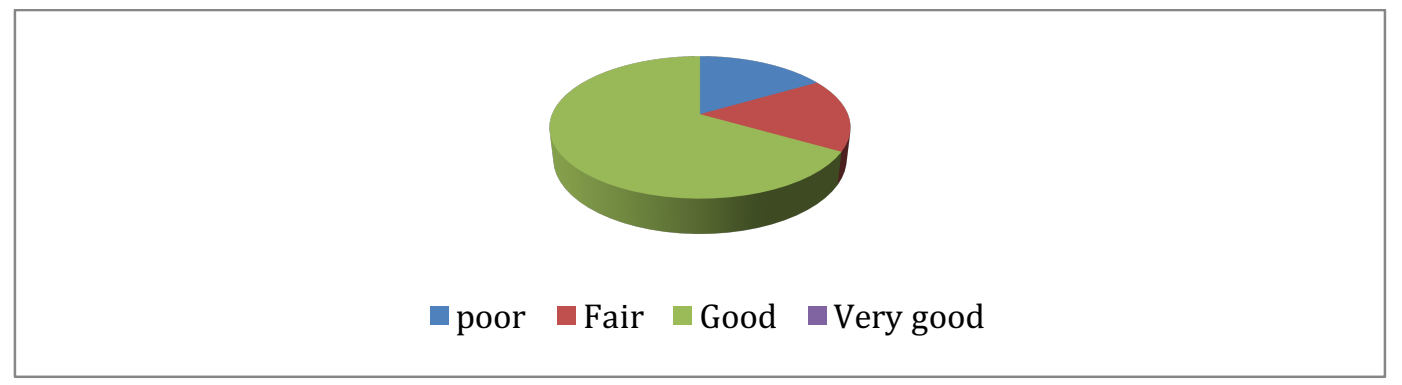

The results of the second question in the questionnaire were:

The results were, only one of the students answered yes, so the percentage was (16.6\%). While the rest of them answered it no, so the percentage was (66.6\%).

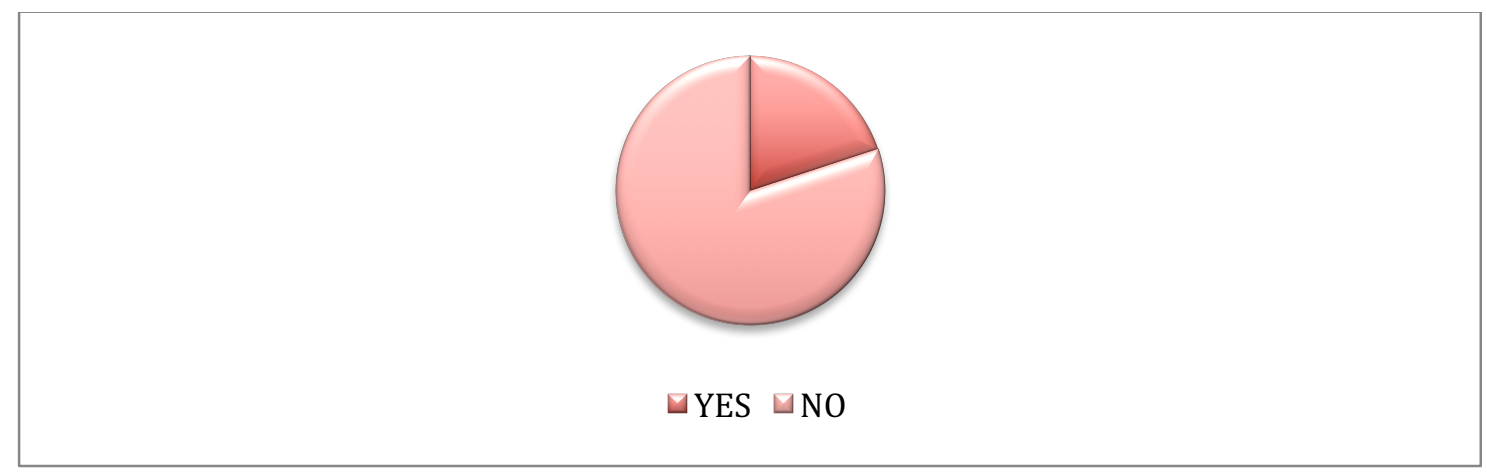

The results of the third question in the questionnaire were:

The result was like, No one of the students answered a lot, so the percentage was (0\%). Four students answered a little, and the percentage was (66.6\%). Also two of them answered never, so the percentage was $(33 \%)$.

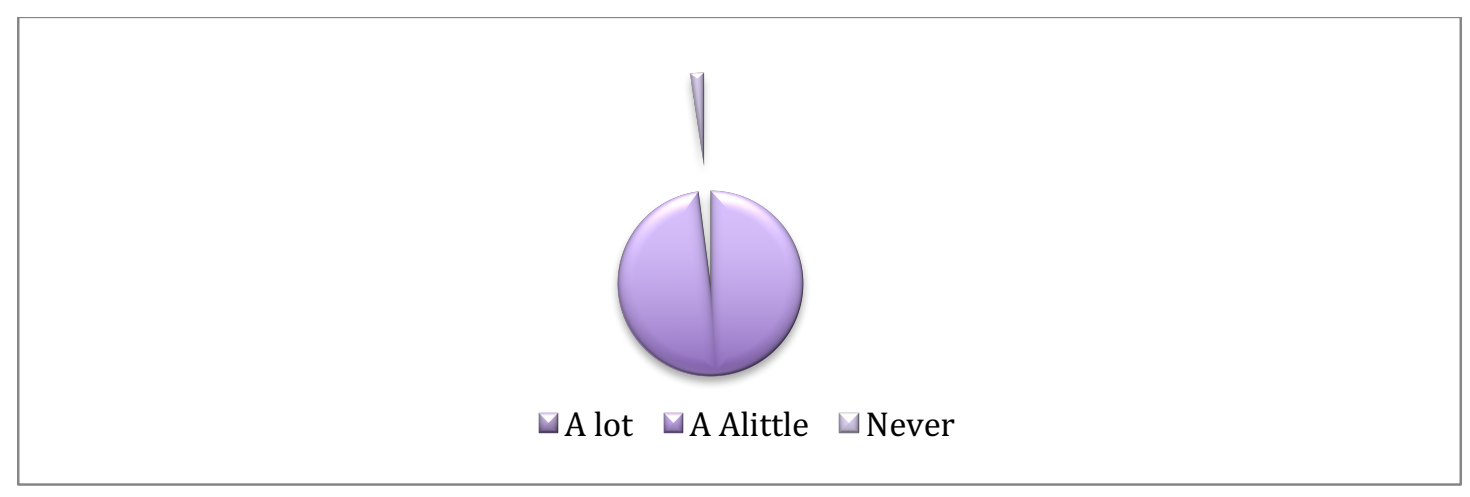




\section{The results of the fourth question in the questionnaire were:}

The result was, four students answered it a lot, so the percentage was (66.6\%). While only one student answered it a little, and it's percentage was (16.6\%). Also only one student answered it never, so the percentage was $(16.6 \%)$.

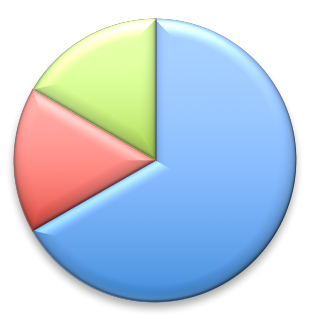

$$
\square \text { Alot } \square \text { Alittle } \square \text { Never }
$$

The results of the fifth question in the questionnaire were:

The result was, one of the students answered it very often, so the percentage was (16.6\%).and no one of them answered it often. So the percentage was $(0 \%)$. Three of the students answered it a few time/month, so the percentage was (50\%). And two of the students answered it never, so the percentage was (33.3\%).

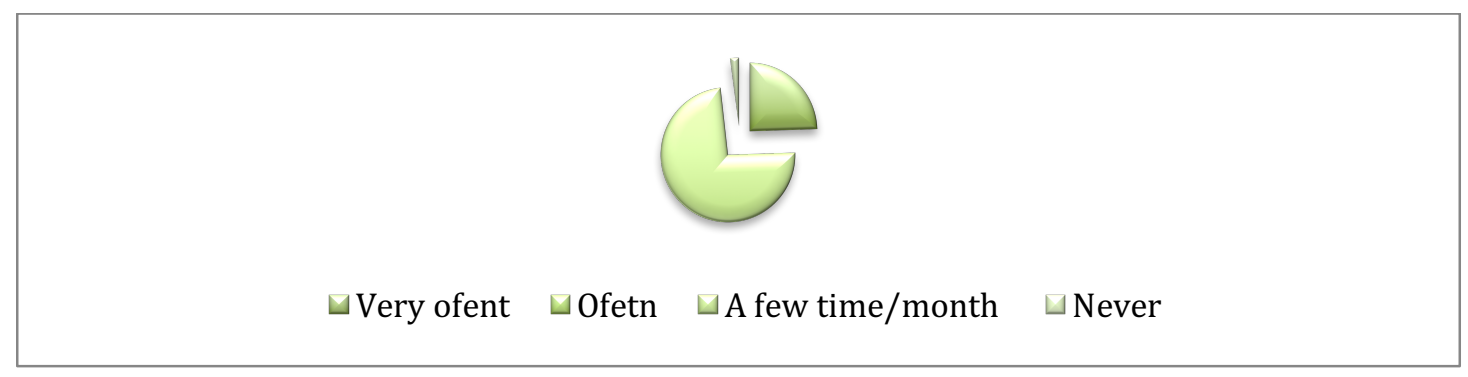

The Analysis of the Practical Activity Given by the researchers to the subjects of the study via Using Computers

The subjects were asked by the researchers to write a 120-150 word paragraph to compare and contrast between the last five years of their life and their life after. Here is the analysis of their answers.

\begin{tabular}{|c|c|c|c|c|c|c|c|c|c|}
\hline \multirow{2}{*}{$\begin{array}{l}\text { Paragraph } \\
\text { Techniques }\end{array}$} & \multicolumn{4}{|c|}{ Format } & \multirow[t]{2}{*}{ Coherence } & \multirow[t]{2}{*}{ Unity } & \multirow[t]{2}{*}{ Conjunctions } & \multirow{2}{*}{$\begin{array}{l}\text { Punctuation } \\
\text { marks }\end{array}$} & \multirow[t]{2}{*}{ Total } \\
\hline & Title & Indent & Margin & $\begin{array}{l}\text { Double } \\
\text { space }\end{array}$ & & & & & \\
\hline $\begin{array}{l}\text { NO. of } \\
\text { Students }\end{array}$ & 1 & 3 & $\mathbf{0}$ & 3 & $\mathbf{0}$ & 2 & 3 & 2 & 4 \\
\hline Percentage & $16.6 \%$ & $50 \%$ & $0 \%$ & $50 \%$ & $0 \%$ & $33.3 \%$ & $50 \%$ & $33.3 \%$ & $66.6 \%$ \\
\hline
\end{tabular}

In this part of the activity only four of the student wrote a paragraph, some of them missed important techniques to write a paragraph, and two of them did not write a word. The researchers analyzed the activity like the following table which shows the result of techniques to write a paragraph: 
Hneesh, M. I., Albawe, F. A. S., \& Asheny, A. A. (2018). An Investigation About Some Difficulties Encountered by Libyan University First Year Students in Writing English Paragraphs via Computers, A Comparative Case Study between the Traditional Way and the Modern Way of Writing English Paragraphs. Advances in Social Sciences Research Journal, 5(10) 149-159.

The following table shows the result of the structure of a paragraph:

\begin{tabular}{|l|l|l|l|l|l|l|l|}
\hline $\begin{array}{l}\text { Paragraph } \\
\text { Structure }\end{array}$ & \multicolumn{2}{|l|}{ Topic sentence } & \multicolumn{2}{l|}{$\begin{array}{l}\text { Supporting } \\
\text { Sentences }\end{array}$} & \multicolumn{2}{l|}{$\begin{array}{l}\text { Concluding } \\
\text { Sentence }\end{array}$} \\
\hline & Used & misused & used & Misused & used & misused & \\
\hline NO. of Students & 1 & 3 & 2 & 2 & 1 & 3 & 4 \\
\hline Percentage & $16.6 \%$ & $50 \%$ & $33 \%$ & $33 \%$ & $16.6 \%$ & $50 \%$ & $66 . \%$ \\
\hline
\end{tabular}

In this part, the six students wrote a paragraph. The researcher analyzed the practical activity. The result for the techniques of a paragraph was like the following table shows:

\begin{tabular}{|c|c|c|c|c|c|c|c|c|}
\hline \multirow{2}{*}{$\begin{array}{l}\text { Paragraph } \\
\text { Technique }\end{array}$} & \multicolumn{4}{|c|}{ Format } & \multirow[t]{2}{*}{ Coherent } & \multirow[t]{2}{*}{ Unity } & \multirow[t]{2}{*}{ Conjunction } & \multirow{2}{*}{$\begin{array}{l}\text { Punctu } \\
\text { ation } \\
\text { Marks }\end{array}$} \\
\hline & title & indent & Margin & $\begin{array}{l}\text { Double } \\
\text { space }\end{array}$ & & & & \\
\hline $\begin{array}{l}\text { NO. of } \\
\text { Students }\end{array}$ & 6 & 6 & 3 & 4 & 4 & 4 & 3 & 4 \\
\hline Percentage & $100 \%$ & $100 \%$ & $50 \%$ & $66.6 \%$ & $66.6 \%$ & $66.6 \%$ & $50 \%$ & 66.6 \\
\hline
\end{tabular}

The following table shows the result of the structure of a paragraph:

\begin{tabular}{|c|c|c|c|c|c|c|c|}
\hline \multirow[t]{2}{*}{$\begin{array}{l}\text { Structure of a } \\
\text { Paragraph }\end{array}$} & \multicolumn{2}{|c|}{ Topic Sentence } & \multicolumn{2}{|c|}{\begin{tabular}{|l} 
Supporting \\
Sentence
\end{tabular}} & \multicolumn{2}{|c|}{$\begin{array}{l}\text { Concluding } \\
\text { Sentence }\end{array}$} & \multirow[t]{2}{*}{ Total } \\
\hline & Used & misused & Used & Misused & used & misused & \\
\hline $\begin{array}{l}\text { NO. of } \\
\text { Students }\end{array}$ & 6 & $\mathbf{0}$ & 4 & 2 & 5 & 1 & 6 \\
\hline Percentage & $100 \%$ & $0 \%$ & $66.6 \%$ & $33 \%$ & $83 \%$ & $16.6 \%$ & $100 \%$ \\
\hline
\end{tabular}

DISCUSSION OF THE RESULTS

This chapter is about the discussion of the results obtained through analyzing the data in chapter three.

\section{The Structure of a Paragraph:}

The results that found in this study was that (16.6\%) of the subjects used the topic sentence with traditional way of writing, but (50\%) misused it. While with via computer (100\%) of the subjects used the topic sentence, and $(0 \%)$ of them misused it. It was found that the supporting sentence used by (33\%) of the subjects, and (33\%) of them misused it when they wrote a traditional paragraph , but when they wrote it with computer $(66.6 \%)$ of them used it and (33\%) misused it. Also the concluding sentence was used by (16.6\%) of the subjects in traditional paragraph writing , and (50\%)of them misused it, but with computer writing paragraph (83\%) of the subject used I, and (16.6\%) of them misused it.

\section{The Characteristics of a Paragraph:}

The subjects faced many problems in techniques of writing a paragraph. In traditional paragraph writing (50\%) used the format of the paragraph, and (50\%) misused ,but in computer writing paragraph (83\%) used the format ,and (16.6\%) misused it. It was found that the subjects faced problems in unity, in traditional writing paragraph $(33 \%)$ of the subjects used it , and (66.6\%) misused it .while via computers for writing paragraphs $(66.6 \%)$ of used it and $(33 \%)$ of the subjects misused. Coherence is another problem that faced the subjects only $(0 \%)$ of them used it in their traditional writing paragraph, and $(100 \%)$ of them misused it , while $(66.6 \%)$ used the coherent in their computer writing paragraph, and (33\%) misused it. 


\section{Conjunctions}

It was found that (50\%) of the subjects used the technique of conjunctions correctly in traditional writing paragraph , and (50\%) of them misused it. By using computers, the results were different , (50\%) of them used the technique correctly, and only(50\%) misused it.

\section{The Punctuation Marks:}

It was found that (33.3\%\%) of the subjects used this technique correctly , and $(66.6 \%)$ of them misused it in traditional writing paragraph .With via computer paragraph the results were different ,(66.6\%) of the subjects used this technique , and (33\%) misused it.

\section{CONCLUSION AND RECOMMENDATIONS}

$\backslash$ This study entitled "A Comparison Between Studying English Writing With a Traditional Way, and Studying English Writing via Computers by University First Year Learners, (English Department), in Paragraph Writing ( Zwara Case) at the College of Arts in Libya". This study aims to help the first year students to study paragraph writing, and make them better writers by using computers, and have technological factors. In the introductory chapter ,it was hypothesized by the researchers that most Libyan Universities ,first year students have no enough knowledge to improve their English writing via computers, especially in writing a paragraph, in that the researchers toke a symbol, from English Department to help and to do their research project.

\section{Conclusion}

First of all, it was concluded that teaching English Writing in classroom is not improved well to the students, and affected on their abilities on writing badly. Secondly, when they have been questioned about their feelings towards English Writing via computer, their motivation has been increased in learning and writing good paragraphs. And Thirdly, when they wrote a paragraph by computer their writing were very improved with all techniques.

Motivation is a major concern in improving reading and consequently fostering literacy (Anderson, Hiebert, Scott \&Wilkinson, 1985), but one should follow up on motivation strategies to check whether they help improve students' achievement in the learned language (Dorneyi, 2001). Using reading texts that students can understand is another motivating factor. Stott (2004) conducted a study on twenty Japanese students taking English classes at a Japanese university to examine whether reading a selection from Japanese literature translated into English would result in better recall and comprehension of the text. Findings indicate that some but not all familiar topics and texts enhance motivation and that teachers should expose students to reading texts from other cultures as well. Teachers should evaluate suitability of the reading materials to their learners in both cases.

Burden (2004) found that students need to realize that the purpose of using the target language is not for studying purposes only but also for effective communication. Moreover, Dorneyi (1998), Ghaith (2003) and Oxford (1996) found that when learners see practical purposes in learning the language, they are motivated even if the language is not significant in the learner's community.

Research has shown that one's positive experiences and achievement in the foreign language impacts one's confidence in using it. Clement (1980) model focused on the influence of the social context on one's motivation in second language learning. He found that positive language learning experiences increase learners' self confidence in using the second language and further motivation to learn it. This even applies to contexts that do not provide direct interaction with native speaker communities. Gardner et al. (2004) agreed that language 
learning in the classroom and in language clubs and activities help increase 'knowledge, fluency and familiarity ....with the language' (p. 3) and shape attitudes to language learning and future use. Dornyei (1994) argued that language learners are motivated differently according to their achievement and self-confidence, and that the learning situation provides motives through the language classroom, i.e. course, teacher and group aspects (Clement, Dornyei, \& Noels, 1994; Csizer \& Dornyei, 2005).

\section{Recommendation}

As the study obtained, the researcher recommended:

1-First year students are new to the whole English department, so they are supposed to be taught well by using technology which could be useful to them better than the traditional way which makes the subjects not applied well, and not interesting.

2- English writing is an important subject, in that it supposed to be taught with attractive new way like giving lectures in lab.

3-To help the students to comprehensive and apply his/her skill in writing, the teacher should give them lectures in labs, and using technical devices like smart board, data show, power point program, and computers.

4-The student will need less time to learn the techniques so the teacher could cover more information, details and notes during a lecture.

\section{References}

Anderson, R. C., Hiebert, E. H., Scott, J. A., \& Wilkinson, L. A. (1985). Becoming a nation of readers. Washington: The National Institutes of Education.

Bangen-Drowns, R. L. (1993). The word processor as an instructional

Burden, P. (2004). An examination of attitude change towards the use of Japanese in a university English 'conversation' class. RELC, 35(1), 21 - 36. doi:10.1177/003368820403500104,

http://dx.doi.org/10.1177/003368820403500104

Byrne, Dom, (1971), Intermediate Compression Passage, Hong Kong.

Clement, R. (1980). Ethnicity, contact, and communicative competence in a second language. In E. Giles, D.

Clement, R., Dornyei, Z., \& Noels, K.A. (1994). Motivation, self -confidence and group cohesion in the foreign language classroom. Language Learning, 44, 417 - 448. doi:10.1111/j.1467-1770.1994.tb01113.x, http://dx.doi.org/10.1111/j.1467-1770.1994.tb01113.x

Dornyei, Z. (1994). Motivation and motivating in the foreign language learning. Language Learning, 40, 46 - 78.

Dornyei, Z., (2001a). Teaching and researching motivation. Essex: Longman.

Dornyei, Z. (2001b). New themes and approaches in second language motivation research. Annual Review of Applied Linguistics, 21, 43 - 61. doi:10.1017/S0267190501000034, http://dx.doi.org/ $10.1017 /$ S0267190501000034.

Fawzia, A. Elbawe, 2007, An Investigation into the Difficulties Encountered by Some Libyan Fourth Year Secondary School Students (English Specialization) Paragraph Writing (A Case Study).

Ghaith, Gh. (2003). The relationship between forms of instruction, achievement and perceptions of classroom climate. Educational Research, 45 (1), 83 - 93. doi:10.1080/0013188032000086145, http://dx.doi.org/ $10.1080 / 0013188032000086145$

Gardener et al. C January (2004).onnectivism: A Learning Theory for the Digital Age. International Journal for Instructional Technology and Distance Learning.

Gardner, R. C. Masgoret, A.M., Tennant, J., \& Mihic, L. (2004). Integrative motivation: Changes during a year-long intermediate level language course. Language Learning, 54(1), 1 - 34. doi:10.1111/j.1467-9922.2004.00247.x, http://dx.doi.org/ 10.1111/j.1467-9922.2004.00247.x 
Kulik, James A. 1994. “Meta-Analytic Studies of Findings on Computer-Based Instruction.” In Baker, Eva L. and O'Neil, Harold F., Jr., eds., Technology Assessment in Education and Training, pp. 9-33. Hillsdale, NJ: Lawrence Erlbaum Associates.

Oshima, Alize. (1978)A, Writing Academic English, Addison, Hesty Press, London.

Rima Bahous, Nahla Nola Bacha, and Mona Nabhan, August 2011, Article in English Language Teaching.

Schuman, J. H. (1978). The acculturation model for second language acquisition. In R. Gingras (Ed.) Second language acquisition and foreign language teaching (pp. 27 - 50). Arlington V.A: Center for Applied Linguistics.

Stott, N. (2004). Familiarity breed contempt: Reading texts from learners' own cultures does not guarantee recall. TESOL Quarterly, 38 (2), 345 - 352. doi:10.2307/3588387, http://dx.doi.org/ 10.2307/3588387 Terrell, S. \& Rendulic, P. (1996). Using computer managed instructional software to increase motivation and achievement in elementary

\section{Citations}

http://wikieducator.org/use_of_computer_in_developing_writing_skills. (2013)

https://neeyhapuzee.wordpress.com/author/neeyhapuzee/January 30, 2011 